\title{
Farmed fish price setting and competition with wild fish in El-Obour wholesale market in Egypt. Ahmed Mohamed Nasr-Allah
}

\section{Introduction}

A rapid rise in aquaculture production has taken place since the early 1980 's. The Egyptian aquaculture increased from 367,000 tonnes in year 2002 to reach 1,018,000 tonnes in year 2012 (GAFRD). Despite this success, the Egyptian aquaculture industry faces a potential market crisis. The cost of inputs, particularly feeds, has increased rapidly (El-Sayed, 2007), while market prices have remained static or declined in real terms. Almost all aquaculture-produced fish is sold whole in fresh or live form to Egyptian consumers as there is very little value addition or export of farmed fish (El-Gayar, 2003; Fitzsimmons, 2008; Norman-López \& Bjørndal, 2009; Macfadyen et al., 2012b).

The main Egyptian wholesale markets for farmed fish are El-Obour (near Cairo) and Kafr el Sheikh in the Nile Delta (Macfadyen et al., 2012a) however there are numerous smaller markets across the country and many smaller retail outlets ranging from formal shops to roadside retailers. El-Obour is the largest and most important fish market in Egypt. It currently has 3 halls for fish, both farmed and wild, with 87 shops working in the fish trade, selling 100 to 150 tonnes of farmed fish per day (Feidi, 2004; Macfadyen et al., 2012a). It has a daily fish auction selling both farmed and wild fish. Prices set at daily auctions are made publically available and published on the EL-Obour website. They appear to influence market prices across the aquaculture industry and are used by wholesalers during negotiations with fish farmers (Macfadyen et al., 2012a).

Fish farmers usually sell their fish at the pond-side to wholesalers who, for a commission of 3-6\% of sales, transport fresh, unprocessed fish to wholesale markets for onward distribution to retailers, or distribute it directly to retailers. In some cases wholesalers have pre-arranged marketing arrangements with fish farmers and may supply credit to them (Feidi, 2004; Macfadyen et al., 2012b). Larger, higher value, tilapia and mullet tend to be transported to city markets, such as El-Obour, near Cairo, whereas smaller fish are sold in rural or poorer urban areas at lower prices (Nasr-Alla et al., 2012). Macfadyen et al. (2012b) stated that farmed fish is sold the same day or the day after and attributed that to the nature of fresh fish sales with or without ice.

Several studies have highlighted the relationship between seasonal fluctuations in supply and prices for farmed fish resulting in a relative scarcity of aquacultureproduced fish, and higher prices, in the early part of the year compared to greater abundance and lower prices later in the year (Kinnucan \& Miao, 1999; Macfadyen et al., 2012a).

However, the local market preferences are for whole, fresh, locally-produced fish as long as prices are competitive (Feidi, 2004) while imports of low value fish species appeared to have an impact on farmed fish prices (Hebicha, 2009; Hebicha et al., 2009). Hebicha (2008) studied fish price transmission between wholesaler and retailer, and concluded that changes in wholesale prices were greater for retail price 
increases than for retail price decreases. Market interactions between farmed fish and the wild fish have been studied in many countries (Asche \& Steen, 1998; Asche et al., 2001; Norman-López \& Asche, 2008; Hong \& Duc, 2009; Norman-López, 2009; Norman-López \& Bjørndal, 2009).

However, only limited studies have been carried out to understand the interactions for farmed fish and competition with wild fish in the Egyptian wholesale market.

\section{Objectives of the study}

This study aimed to investigate price formation of farmed fish in El-Obour wholesale market between $1^{\text {st }}$ January 2012 and $31^{\text {st }}$ December 2012. Moreover, the study aimed to understand farmed fish price competition with low value wild frozen fish in the same wholesale market. Specifically the objectives of the study are:

1. to study the relationship between supply volumes and selling prices for farmed fish in wholesale market.

2. to test market integration between different farmed fish products in the same market.

3. to test market integration between wild frozen fish and farmed fish in wholesale market.

In the following section, the paper discusses Egyptian aquaculture development with a special focus on the main cultured species.

\section{Egyptian aquaculture development}

Almost all Egyptian aquaculture production is carried out in earth ponds which are concentrated in low-lying areas where water from irrigation systems drains into Northern coastal lakes (Burullus, Manzala and Edku) (El-Gayar, 2003; Nasr-Alla, et al., 2012). Most fish farmers stock their ponds with sex-reversed Nile tilapia (Oreochromis niloticus) and mullet (wild-caught Mugil cephalus and Liza ramada) fingerlings once temperatures start to rise in April to May and harvest fish before temperatures drop at the end of the year (Macfadyen et al., 2012b). Productivity has increased from 3 tonnes/ha in 1991 (Radwan, 2008) and 4 tonnes/ha in 1994 (Green et al., 2002) to reach average production levels of 8.5 tonnes/ha in 2011 (Nasr-Alla et al., 2012). National aquaculture production increased from 376,000 tonnes in 2002 to reach 1,018,000 tonnes in 2012 (table 1) (GAFRD, 2014), at an average annual increase of $11 \%$ over the same period. Meanwhile, tilapia production grew by an average of $17 \%$ during the same time (table1). According to national statistics Nile tilapia (Oreochromis niloticus) accounts for $75 \%$ of national aquaculture production by volume, while mullets account for 13\% (grey mullet (Mugil cephalus) and thinlip mullet (Liza ramada)), carps accounts for 6.6\% (common carp (Cyprinus carpio), grass carp (Ctenopharyngodon idella), and silver carp (Hypophthalmichthys molitrix), African catfish (Clarias gariepinus) for 2.3\%, and European seabass (Dicentrarchus labrax) and gilthead seabream (Sparus aurata) for 2.8\% (GAFRD 2012).

\section{Market data}

The primary data source for this study is daily fish sales data on sales volumes and the average selling price of different fish species in El-Obour wholesale fish 
Table (1) : Total aquaculture and tilapia production in Egypt (000 tonnes/ year) and \% annual increases in production. 2002 and 2012.

\begin{tabular}{|c|c|c|c|c|c|c|c|c|c|c|c|}
\hline & $\mathbf{2 0 0 2}$ & $\mathbf{2 0 0 3}$ & $\mathbf{2 0 0 4}$ & $\mathbf{2 0 0 5}$ & $\mathbf{2 0 0 6}$ & $\mathbf{2 0 0 7}$ & $\mathbf{2 0 0 8}$ & $\mathbf{2 0 0 9}$ & $\mathbf{2 0 1 0}$ & $\mathbf{2 0 1 1}$ & $\mathbf{2 0 1 2}$ \\
\hline $\begin{array}{c}\text { Total } \\
\text { aquaculture } \\
\text { production } \\
\text { (000 tonnes) }\end{array}$ & 376 & 445 & 472 & 540 & 595 & 636 & 694 & 705 & 922 & 987 & 1.018 \\
\hline $\begin{array}{c}\text { Tilapia } \\
\text { production } \\
\text { (000 tonnes) }\end{array}$ & 168 & 200 & 199 & 217 & 259 & 266 & 386 & 390 & 557 & 611 & 769 \\
\hline $\begin{array}{c}\text { \% increase in } \\
\text { aquaculture } \\
\text { production }\end{array}$ & $10 \%$ & $18 \%$ & $6 \%$ & $14 \%$ & $10 \%$ & $7 \%$ & $9 \%$ & $2 \%$ & $31 \%$ & $7 \%$ & $3 \%$ \\
\hline $\begin{array}{c}\text { \% increase in } \\
\text { tilapia } \\
\text { production }\end{array}$ & $10 \%$ & $19 \%$ & $-1 \%$ & $9 \%$ & $19 \%$ & $3 \%$ & $45 \%$ & $1 \%$ & $43 \%$ & $10 \%$ & $26 \%$ \\
\hline
\end{tabular}

Average increase in aquaculture production is $11 \%$

Average increase in tilapia production is $17 \%$

Data Source: GAFRD statistics year book

market near Cairo over the period $1^{\text {st }}$ January to $31^{\text {th }}$ December 2012 (www.oboormarket.org.eg/prices.aspx). The number of observations for the study is 349 working days. Market data was collected on the following farmed species: Nile tilapia (Oreochromis niloticus); mullet (flathead grey mullet, Mugil cephalus and thin-lipped mullet, Liza ramada); African catfish (Clarias gariepinus); and the following wild species: mackerel (Scomber scombrus); lizardfish (Saurida spp.); sardine (Sardinella spp.) and Mediterranean horse mackerel (Trachurus mediterraneus).

There are specific market size grades of tilapia; tilapia grade 1 (375-600 g), grade 2 (250-375 g), and grade 3 (100-250 g).

\section{Data processing and analysis}

The daily data was summarized into monthly and yearly series for each species/type. MS Excel was used for descriptive statistics (sum, mean and charts). Regression analysis was performed using IBM SPSS statistical software package, version 19 (SPSS) as described by Field, A, 2009). In order to perform Johansen Cointegration analysis, the econometric software package EViews 5.0 was used (EViews, 2004). For cointegration test, fish price data transformed into logarithms before the analysis.

\section{Methodology}

Regression analysis

To establish the relationship between fish sales volumes and sale prices for each fish species/type separately, regression analysis was carried out. A simple regression model was used as follows:

$$
\mathrm{Y}=\mathrm{B}_{0}+\mathrm{B}_{1} \mathrm{X}
$$

Where; $\mathrm{Y}=$ dependent variable (fish prices $\mathrm{LE} / \mathrm{Kg}$ ); $\mathrm{B}_{0}=$ constant; $\mathrm{B}_{1}=$ slope regression coefficient and $\mathrm{X}=$ independent variable (fish supply in tonnes/day).

Testing market integration

In order to determine the extent to which each type of fish was competing in a single market there was a need to measure whether there were relationships between price fluctuations for each species over the study time period. The Johansen Test for cointegration was used with the main condition for using this test being that the price 
series shows nonstationary probability (Asche, et al., 2004; Norman-López \& Asche, 2008, Norman-López, 2009).

For testing the time series properties of price series data, the study used the most common approach, the Augmented Dickey-Fuller (ADF) test (Dickey \& Fuller 1979). Automatic selection of Schwartz information criterion (SIC) was used as the basis for determining the optimal lag length, where the maximum number of lags was ten. In this study we ran the ADF test with and without a constant as the prices of most species do not fluctuate around a constant. The Augmented Dickey-Fuller (ADF) tests carried out using the formula as described by (Asche, et al., 2004).

$\Delta p_{i t}-\beta_{o}+\beta T+\sigma p_{i t-1}+\sum_{\gamma=1}^{k} \alpha_{\gamma} \Delta p_{i t-\gamma}+c_{t}$

Where: $p_{i t}$ is each individual price, $\Delta$ is the difference operator, $\mathrm{T}$ is the time trend, $\mathrm{k}$ is the lag length, $\gamma$ is estimated coefficient, and $\varepsilon_{z}$ is the error term.

The Johansen cointegration test (Johansen 1988) used for this article as it provides good solution for testing cointegration by modelling the price relationship in VAR format and it allows testing the 'Low of One Price' (LOP) (Norman-López \& Asche 2008). The mathematical model carried out as described in detail by (Asche, et al., 2004).

The Johansen test was carried out using the following VAR representation; $\Gamma_{*}=\sum_{i=1}^{k-1} \prod_{i} p_{t-i}\left\|\prod_{k} p_{t-k}\right\| \mu \| e_{t}$

Where: each $\Pi$ is a $\mathrm{N} \times \mathrm{N}$. matrix of parameters, $\mu$ is a constant term and $\mathrm{e}_{\mathrm{t}}^{\sim} \mathrm{iid}(0, \mathrm{~W})$. The system of equations can be written in error correction form as $\Delta P_{t}=\sum_{i=1}^{k-1} \Gamma_{i} \Delta \Gamma_{t-i}\left|\Gamma_{k} \Gamma_{t-k}\right| \mu \| e_{t}$

Where: $\Gamma_{\mathrm{i}}=-1+\Pi_{1}+\ldots+\Pi_{\mathrm{i}}$ and $\mathrm{i}=1, \ldots, \mathrm{k}-1$. Here $\Gamma \mathbf{k}$ is the long-run "level solution" to equation (2). The rank of $\Gamma_{\mathrm{k}}$, defined by $\mathrm{r}$, determines how many liner combinations of $P_{t}$ is stationary. If $\mathrm{r}=\mathrm{N}$, the variables are stationary in levels; if $\mathrm{r}=0$, none of linear combinations are nonstationary. When $0<\mathrm{r}<\mathrm{N}$ there exist $\mathrm{r}$ liner stationary combinations of $P_{t}$ or $\mathrm{r}$ cointegrating vectors (Norman-López \& Bjørndal, 2009).

With cointegrated data series, one can factor $\Gamma \mathrm{k}$, such that $\Gamma \mathrm{k}=\alpha \beta^{\prime}$, where $\alpha$ and $\beta$ are both $\mathrm{N} \times \mathrm{r}$ matrices of rank $\mathrm{r}$. The cointegrating vectors or the long-run relationships in the system are contained in the $\beta$ matrix. The adjustment parameters on the other hand are identified in the parameters contained in $\alpha$. Two alternative tests that are used to identify the number of significant cointegrating vectors $r$, the trace test and the maximum eigenvalue test both of which are discussed in detail in Johansen (1995). The two tests have the null hypothesis that there are at most $r$ cointegration vectors. The alternative hypothesis in the trace test is that there exist more than $r$ cointegration vectors while for the maximum eigenvalue test, the alternative hypothesis is that there are exactly $\mathrm{r}+1$ cointegration vectors.

For testing the Law of One Price (LOP), restrictions can be placed and tested on the parameters in the $\beta$ matrix. In the case of a bivariate system where two price series are examined, the rank of $\Pi=\alpha \beta^{\prime}$ would be equal to 1 and the dimensions of $\alpha$ and $\beta$ matrices would be $2 \times 1$. LOP is tested by imposing the restriction $\beta^{\prime}=(1,-1)$. 
Since the matrix $\beta$ contains long-run parameter in the system the test can be considered a test of the validity of LOP as a long-run concept. The equation used for the LOP test was as follows:

$p_{t}^{1}=\propto+\sum_{j=1}^{m} b_{j} p_{z-j}^{\frac{1}{z}}+\sum_{i=0}^{n_{1}} c_{i} p_{t-i}^{\underline{Z}}+e_{z}$

The test for long run LOP tests the restriction $\Sigma b_{j}+\Sigma c_{i}=1$. If the restrictions $c_{0}=1$, $c_{i}=0$, and $b_{j}=0, \forall_{i j}>0$ cannot be rejected, this should be considered as evidence that it is statistically significant.

\section{Results}

\section{Wholesale market data analysis}

Table 2 shows the total quantities of different types of fish supplied to ElObour Market during 2012, the average amount per day (for days when it was available) and average sales prices per kilogram during the year. The highest quantity of fish sold in 2012 was the farmed tilapia grade 1 (T1) followed by wild-caught Aswan tilapia (AT), tilapia grade 2 (T2), wild-caught frozen Mediterranean horse mackerel (MHM) and wild-caught frozen mackerel (FM). The total amount of farmed fish supplied to the market was 33,152 t/yr (95,5 t/day) while the total sales volume of wild fish was $25,975 \mathrm{t} / \mathrm{yr}$ ( 89,7 tons/day). Different grades of farmed tilapia sales represent the majority $(88 \%)$ of aquaculture-produced fish sold in the market. NasrAlla et el (2012) in their value chain analysis of the Egyptian aquaculture, found that tilapia represented $89 \%$ of total farmed fish production.

Table (2) : Quantities of fish supplied to El-Obour market in tonnes and average selling prices $(\mathrm{LE} / \mathrm{kg})$ during 2012

\begin{tabular}{|l|c|c|c|}
\hline \multicolumn{1}{|c|}{ Fish Species/grades } & Quantity (t/yr) & $\begin{array}{c}\text { Average daily } \\
\text { supply (t/day) }\end{array}$ & $\begin{array}{c}\text { Average price } \\
\text { LE/kg }\end{array}$ \\
\hline Farmed Fish & 15.352 & 43.99 & 11.43 \\
\hline Tilapia grade 1 (T1) & 12.227 & 35.03 & 9.06 \\
\hline Tilapia grade 2 (T2) & 1.824 & 5.35 & 5.24 \\
\hline Tilapia grade 3 (T3) & 3.162 & 9.44 & 10.57 \\
\hline Catfish (CF) & 587 & 1.73 & 25.04 \\
\hline Mullet & 12.956 & 37.45 & 9.41 \\
\hline Wild Fish & 5.864 & 31.70 & 3.26 \\
\hline Aswan tilapia (AT) & 3.486 & 10.02 & 10.09 \\
\hline Mediterranean horse mackerel (MHM) & 2.744 & 7.89 & 7.55 \\
\hline Frozen mackerel (FM) & 925 & 2.64 & 5.7 \\
\hline Frozen sardine (FS) & \multicolumn{3}{|l}{} \\
\hline Frozen lizardfish (FL) &
\end{tabular}

Source: El-Obour market data base.

Figures 1 and 2 show changes of sales volumes and selling prices for the main species throughout the year; T1, T2, AT, MHM and FM. The supply of tilapia to ElObour market shows a seasonal pattern (Figure 1). Supplies of farmed tilapia (T1 and T2) were lowest in March to May and highest in September through to December, reflecting greater availability of the larger farmed fish grades from fish stocked in early 2012. As might be expected, prices for farmed tilapia peaked in April when $20 \%$ less than the average was being supplied to the market, and were at their lowest in September and October when supplies increased. Supplies and prices of wild Aswan tilapia (AT) appeared to follow similar patterns, but with less fluctuation in prices, perhaps because of price controls in Aswan (Bene et al., 2008). Mediterranean 
horse mackerel (MHM) is wild caught fish from the Eastern Mediterranean which is stored before being released to the market when farmed tilapia is in short supply.

Figure 1. Monthly fluctuations in the supply of the five main fish types to ElObour market (\% deviation from average annual).

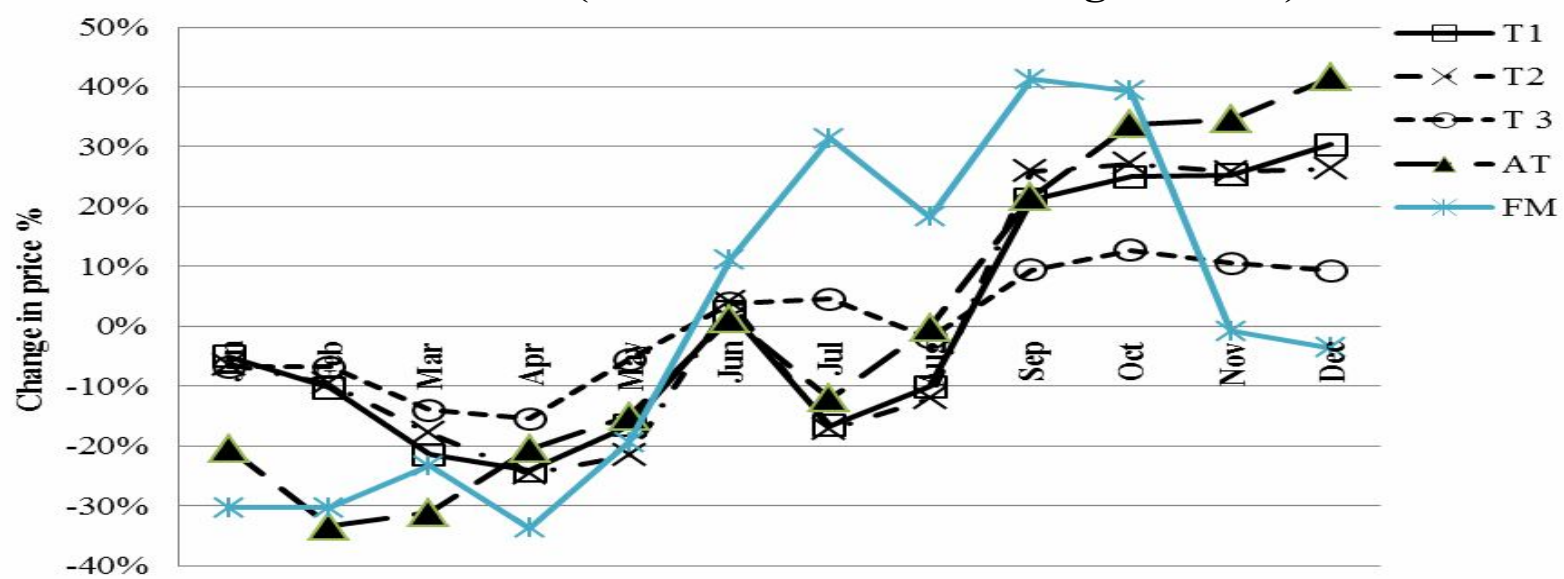

Month

Figure 2. Monthly fluctuations in wholesale prices for the five main fish types traded in El-Obour market (\% deviation from average annual price).

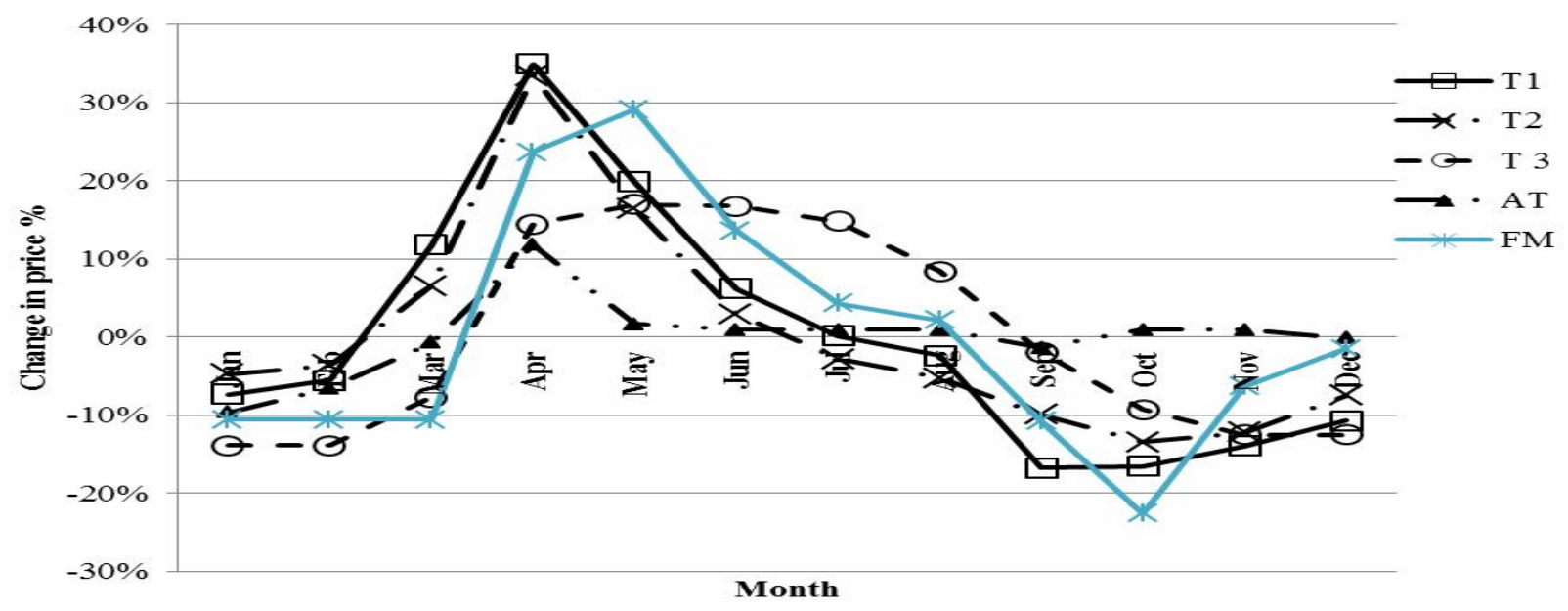

Figure 3, shows the response in fish selling prices to changes in sales volumes for different grades of farmed tilapia and wild Aswan tilapia on a monthly basis. For $\mathrm{T} 1, \mathrm{~T} 2$ and $\mathrm{T} 3$, there is an inverse relationship as the fish price increases when the sales volume decreases which was confirmed by linear regression analysis for each species/grade separately (Table 3 ). For $\mathrm{T} 1$, a one tonne $(2.3 \%)$ increase in daily supply to the market would lead to a price decrease of $0.12 \mathrm{LE} / \mathrm{kg}(1 \%)$. Similarly, a one tonne (3\%) increase in daily supply of T2 would lead to reduction of selling price by $1 \%$. T3 selling prices showed the lowest sensitivity among farmed tilapias to changes in daily supply volume. A one tonne $(19 \%)$ increase in daily supply to the market would lead to a price decrease of $0.17 \mathrm{LE} / \mathrm{kg}(3.3 \%)$.

A similar inverse relationship was established for frozen mackerel where an increase in sales volume of $10 \%$ would lead to a $2 \%$ reduction in selling price. Regression analysis indicated that the inverse relationship between sales volume and prices was less clear for frozen sardine and mullet. In contrast, increased sales volumes of Aswan tilapia, frozen lizardfish and African catfish did not lead to significant reductions in selling prices; in the case of Aswan tilapia this may be 
because the supply route for this fish is highly regulated. Catfish fellow similar pattern as of AT and lizardfish as sales price of CF also did not decline with increase sales volume

Table (3) : Linear regression analysis of 2012 daily market prices and volumes in El-Obour market

\begin{tabular}{|c|c|c|c|}
\hline Fish type & Linear regression equation & $\begin{array}{c}\text { Statistical } \\
\text { significance }\end{array}$ & R \\
\hline Tilapia grade 1 (T1) & $\hat{\mathrm{Y}}=-0.119 \mathrm{X}+16.673$ & 0.000 & 0.645 \\
\hline Tilapia grade 2 (T2) & $\hat{\mathrm{Y}}=-0.088 \mathrm{X}+12.158$ & 0.000 & 0.628 \\
\hline Tilapia grade 3 (T3) & $\hat{\mathrm{Y}}=-0.170 \mathrm{X}+6.144$ & 0.002 & 0.168 \\
\hline Catfish (CF) & $\hat{\mathrm{Y}}=0.221 \mathrm{X}+8.485$ & 0.000 & 0.342 \\
\hline Mullet & $\hat{\mathrm{Y}}=-0.089 \mathrm{X}+25.198$ & 0.148 & 0.079 \\
\hline Aswan tilapia (AT) & $\hat{\mathrm{Y}}=0.005 \mathrm{X}+9.211$ & 0.056 & 0.103 \\
\hline $\begin{array}{c}\text { Mediterranean horse } \\
\text { mackerel (MHM) }\end{array}$ & $\hat{\mathrm{Y}}=-0.27 \mathrm{X}+4.105$ & 0.004 & 0.212 \\
\hline Frozen mackerel (FM) & $\hat{\mathrm{Y}}=-0.195 \mathrm{X}+12.052$ & 0.000 & 0.352 \\
\hline Frozen sardine (FS) & $\hat{\mathrm{Y}}=-0.034 \mathrm{X}+7.818$ & 0.424 & 0.043 \\
\hline Frozen lizardfish (FL) & $\hat{\mathrm{Y}}=0.989 \mathrm{X}+3.088$ & 0.000 & 0.854 \\
\hline
\end{tabular}

Where. $Y=$ Fish price $(\mathrm{LE} / \mathrm{Kg})$; $X=$ fish quantity (tonnes); $R=$ correlation coefficient Source: calculated from table (1), table (2).

Figure 3. Change in sales prices according to sales volume in El-Obour market for T1, T2, T3 and wild Aswan tilapia (AT).

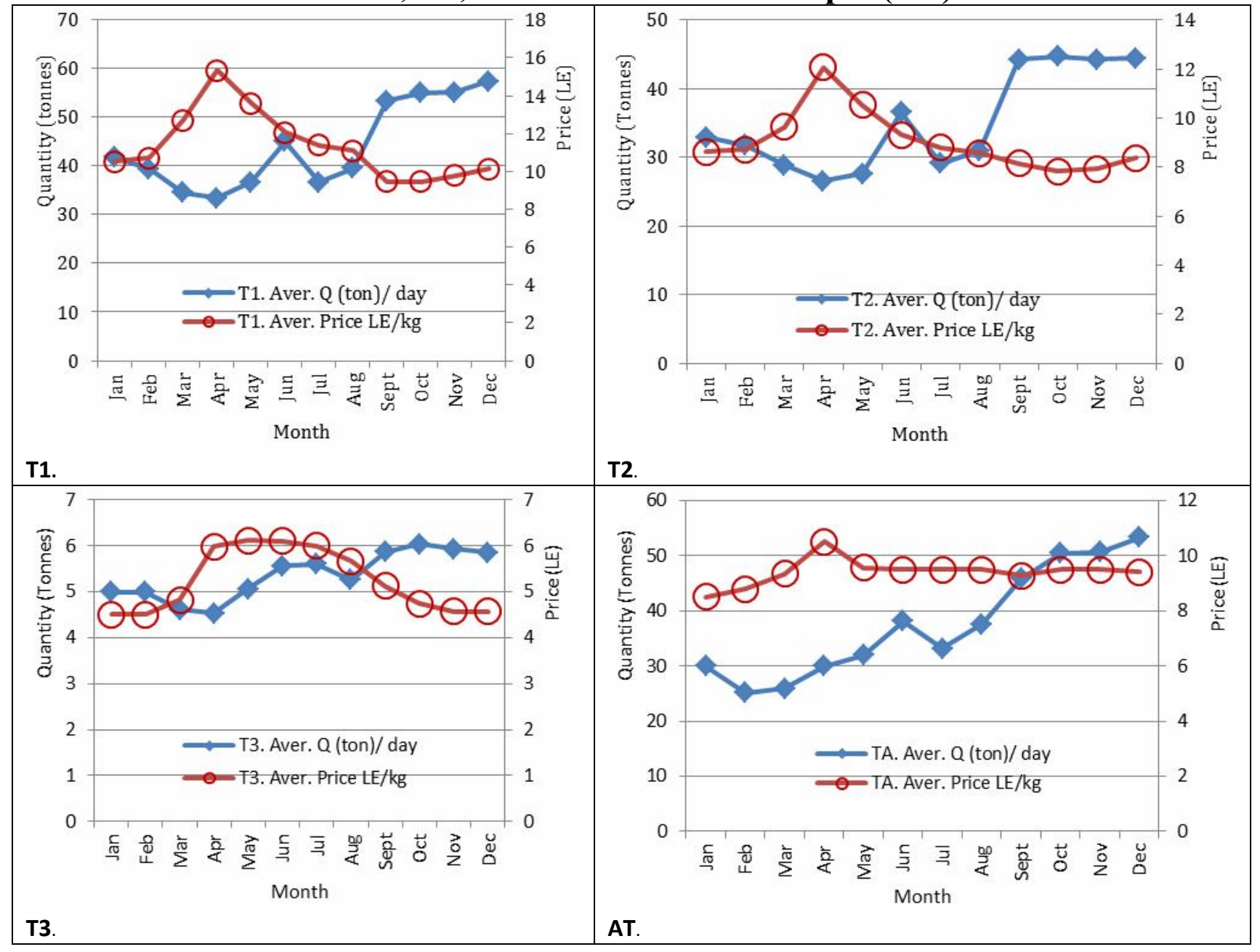


Table 4 shows the Augmented Dickey-Fuller tests on log nominal prices for each species/type. Numbers of lags for the Schwarz information criteria for each $\mathrm{ADF}$ test are shown in parentheses. The large number of lags chosen for the MHM price series is due to their high seasonal variability in the market. The null hypothesis of the test is that the data series is nonstationary. The test results indicate that the logarithmic time series data are nonstationary at level for T1, T2, T3, CF, FS, MHM and FL. As a result of this test, species which were stationary (mullet, AT and FM) at levels were excluded from the Johansen cointegration test.

Table (4) : Augmented Dickey-Fuller test (unit root test) for fish log nominal prices. January- December $2012(\mathrm{n}=\mathbf{3 4 9})$

\begin{tabular}{|l|c|c|c|c|}
\hline \multirow{2}{*}{} & \multicolumn{2}{|c|}{ levels } & \multicolumn{2}{c|}{ First difference } \\
\cline { 2 - 5 } & Constant & $\begin{array}{c}\text { Constant \& } \\
\text { Trend }\end{array}$ & Constant & $\begin{array}{c}\text { Constant \& } \\
\text { Trend }\end{array}$ \\
\hline Farmed fish & & & & \\
\hline Tilapia grade 1 (T1) & $-2.010(1)$ & $-2.579(1)$ & $-24.871^{* *}(0)$ & $-24.848^{* *}(0)$ \\
\hline Tilapia grade 2 (T2) & $-2.292(0)$ & $-2.899(0)$ & $-20.303^{* *(0)}$ & $-20.293^{* *}(0)$ \\
\hline Tilapia grade 3 (T3) & $-1.618(1)$ & $-1.676(1)$ & $-21.2926^{* *}(0)$ & $-21.332^{* *}(0)$ \\
\hline Catfish (CF) & $-1.412(1)$ & $-2.106(3)$ & $-15.681^{* *(2)}$ & $-15.663^{* *(2)}$ \\
\hline Mullet & $-5.329^{* *}(1)$ & $-5.332^{* *}(1)$ & $-11.348^{* *(6)}$ & $-11.396^{* *}(6)$ \\
\hline Wild Fish & & & & \\
\hline Aswan tilapia (AT) & $-2.987^{*}(2)$ & $-2.949(2)$ & $-15.823^{* *(2)}$ & $-15.821^{* *(2)}$ \\
\hline $\begin{array}{l}\text { Mediterranean horse } \\
\text { mackerel (MHM) }\end{array}$ & $-1.391(10)$ & $-1.518(9)$ & $-24.237^{* *}(0)$ & $-24.167^{* *}(0)$ \\
\hline Frozen mackerel (FM) & $-3.085^{*}(3)$ & $-3.129(3)$ & $-14.313^{* *(3)}$ & $-14.293^{* *}(3)$ \\
\hline Frozen sardine (FS) & $-0.465(3)$ & $-1.424(3)$ & $-9.311^{* *}(2)$ & $-9.400^{* *}(2)$ \\
\hline Frozen mackerel (FM) & $-3.085^{*}(3)$ & $-3.129(3)$ & $-14.313^{* *}(3)$ & $-14.293^{* *}(3)$ \\
\hline Frozen lizardfish (FL) & $-1.569(0)$ & $-1.622(0)$ & $-20.830^{* *(0)}$ & $-20.838^{* *(0)}$ \\
\hline
\end{tabular}

* indicate significant at $5 \%$ level; ** indicate significant at $1 \%$ level

The value in brackets indicate number of lags

Source: calculated from table (1), table (2).

For nonstationary price series data used for testing selling price associations in the market and testing for the LOP, cointegration procedures are the correct tools for analysis (Asche et al., 2004; Norman-López and Asche 2008; Norman-López and Bjørndal 2009). The results of applying the Bivariate Johansen cointegration test for measuring wholesale price associations are listed in detail in table 5. Six, separate, pairwise tests were carried out for different grades of tilapia and catfish. Mullet is excluded from this analysis as the time series of it is price stationary. The value of the calculated statistics for the maximum eigenvalue and trace test (columns two and three) for testing the null hypothesis indicates that there is no cointegrating vector. The tests repeated in columns four and five under the null hypothesis indicate that there is less than or equal to one cointegrating vector. The test result of the LOP is shown in the last column.

When the null hypothesis of no cointegrating vector Rank $(\rho)=0$ is rejected at the $1 \%$ or $5 \%$ level, that allows rejection of the hypothesis of zero cointegrating vectors. That applied only with $\mathrm{T} 1$ and $\mathrm{T} 2$. Also the null hypothesis of less than or equal to one cointegrating vector Rank $(\rho) \leq 1$ could not be rejected at the $1 \%$ level except for T1 and T2. The combination of the two sets of results indicates more than one cointegrating vector exists for tilapia grade 1 and tilapia grade 2 . The results indicate that tilapia 1 and tilapia 2 are operating in the same market. On the other 
hand catfish and different grades of tilapias fail to reject the null hypnosis of no cointegration vector at rank $=0$ at $5 \%$ significance level. As result there is no market integration between catfish and different grades of tilapias, and catfish are presented separately in the market as they are unrelated products.

Table (5) : Bivariate Johansen tests for cointegrations of T1. T2. T3 and catfish prices in El-Obour wholesale market. Jan 2012 to Dec. $2012(n=349)$

\begin{tabular}{|c|c|c|c|c|c|}
\hline \multirow{2}{*}{ Prices } & \multicolumn{5}{|c|}{ Null Hypotheses $^{\mathbf{a}}$} \\
\cline { 2 - 6 } & $\mathbf{M a x}^{\mathbf{b}}$ & Trace $^{\mathbf{c}}$ & $\mathbf{M a x}^{\mathbf{b}}$ & Trace $^{\mathbf{c}}$ & \multirow{2}{*}{ Law of One Price (LOP) } \\
\hline T1 \& T2 & $29.489^{* *}$ & $33.419^{* *}$ & $3.930^{*}$ & $3.930^{*}$ & $8.010^{* *}$ \\
\hline T1 \& T3 & 10.655 & 13.223 & 2.568 & 2.568 & - \\
\hline T2 \& T3 & 12.199 & 14.875 & 2.675 & 2.675 & - \\
\hline T1 \& CF & 6.606 & 9.800 & 3.194 & 3.194 & - \\
\hline T2 \& CF & 6.359 & 10.505 & $4.146^{*}$ & $4.146^{*}$ & - \\
\hline T3 \& CF & 6.192 & 9.099 & 2.907 & 2.907 & - \\
\hline
\end{tabular}

a the null hypothesis is that the number of cointegrating vectors is equal to $\rho$;

$b$ maximum eigenvalue test;

c trace test.

** Indicates significance at the $1 \%$ level.

* Indicates significance at the $5 \%$ level.

Source: calculated from table (1), table (2).

Table 6, shows the result of bivariate Johansen cointegrated tests between farmed fish and the most popular wild fish in the market. The test results show that the null hypothesis of no cointegration at rank $=0$ is rejected for sardine with $\mathrm{T} 1$ and T2. Also the results reveal that farmed $\mathrm{T} 2 \& \mathrm{~T} 3$ are cointegrated with frozen lizardfish. Similarly the null hypothesis of no cointegration at rank $=0$ is rejected at $1 \%$ significance level for Mediterranean horse mackerel (MHM) only for T3. This indicates that there is market integration between wild fish and at least one grade of tilapia in the market and that wild fish supply could influence tilapia prices.

Table (6) : Bivariate Johansen tests for cointegrations of farmed tilapia prices with other substitute in El-Obour wholesale warket. Jan 2012 to Dec. $2012(n=341)$

\begin{tabular}{|c|c|c|c|c|c|}
\hline & \multicolumn{4}{|c|}{$\begin{array}{l}\text { Null Hypotheses }^{\mathrm{a}} \\
\end{array}$} & \multirow{3}{*}{ Law of One Price (LOP) } \\
\hline \multirow{2}{*}{ Prices } & \multicolumn{2}{|c|}{$\operatorname{Rank}(\rho)=0$} & \multicolumn{2}{|c|}{$\operatorname{Rank}(\rho)=1$} & \\
\hline & $\operatorname{Max}^{6}$ & Trace $^{c}$ & $\mathbf{M a x}^{\mathbf{b}}$ & Trace $^{c}$ & \\
\hline T1 \& MHM & 6.833 & 7.349 & 0.515 & 0.515 & - \\
\hline T1\& FS & $19.261^{* *}$ & $19.859 *$ & 0.597 & 0.597 & $13.228^{* *} *$ \\
\hline T1 \& FL & 9.924 & 13.917 & $3.993^{*}$ & $3.993^{*}$ & $54.841^{* *}$ \\
\hline T2 \& MHМ & 14257 & 14445 & 0188 & 0188 & - \\
\hline T2 \& FS & $18.098^{*}$ & $18.766^{*}$ & 0.667 & 0.667 & $16.470^{* *}$ \\
\hline T2 \& FL & 11.681 & $16.661^{*}$ & $4.981^{*}$ & $4.981^{*}$ & $16.350^{* *}$ \\
\hline T3 \& MHM & $18.188^{*}$ & $18.844^{*}$ & 0.656 & 0.656 & $9.060 * *$ \\
\hline T3 \& FS & 9.674 & 9.770 & 0.096 & 0.096 & - \\
\hline T3 \& FL & $19.185^{* *}$ & $21.465 * *$ & 2.279 & 2.279 & $15.264 * *$ \\
\hline CF \& MHM & 12.475 & 14.436 & 1962 & 1962 & - \\
\hline CF \& FS & 4.056 & 4.546 & 0.49 & 0.49 & - \\
\hline CF \& FL & 5.643 & 8.967 & 3.324 & 3.324 & - \\
\hline
\end{tabular}

a the null hypothesis is that the number of cointegration vector is equal to zero or one.

b maximum eigenvalues test

c trace test

* indicate significance at the $5 \%$ level; ** indicate significance at the $1 \%$ level

Source: calculated from table (1), table (2). 
On the other hand the test failed to the reject the null hypothesis at rank $=0$ at $5 \%$ significance level in case of catfish for the three wild fish species (FL, FS and MHM). Therefore market integration is not found between catfish and wild fish in ElObour market. So the most popular wild fish species do not compete in the same market as farmed catfish.

\section{Discussion and Conclusions}

This article aimed to investigate the interaction in El-Obour wholesale market. The current study is important as it contributes to understand the competition of farmed fish and wild fish in the market. The study shows that there are significant regression coefficients between selling prices and sales volumes for tilapia grades 1 , 2 and 3. There is also a significant inverse relationship between sales volumes and selling prices of mackerel and Mediterranean horse mackerel. This explains why farmed fish prices decline from September to December as a result of increasing supply, while during the low supply season from March to May, farmed tilapia selling prices increase. Macfadyen et al. (2012a; 2012b) reported that Egyptian fish farming is seasonal as most farmers stock in April-May and harvest in SeptemberDecember before the on-set of winter.

This research indicates that markets for farmed tilapia and African catfish are separate as are the markets for African catfish and wild fish. This agrees with the findings of Norman-López and Asche (2008) and Norman-López (2009) on their study of fresh tilapia fillet and fresh catfish fillet in US markets but contradicts the findings of Hong and Duc (2009) who stated that there is a relationship between catfish and other fish species in US fish markets in which domestic catfish and imported catfish were the closest substitutes. Moreover they reported that there are substitution relationships between goods such as imported catfish and domestic catfish; domestic catfish and tilapia; domestic catfish and salmon in US market.

Our research indicates that frozen sardines are in the same market as T1 and T2, while frozen lizardfish competes with T2 and T3 and Mediterranean horse mackerel competes only with tilapia grade 3 . The implication of that is that increased farmed tilapia production is well placed to the gap in declining market supplies of wild fish. Asche et al (2001) found that there was a close market relationship between different (farmed and wild) salmon species but little market interaction between farmed fish and other wild species in US and EU markets.

Hebicha and Salama (2008) reported that the Egyptian fish farmers' share of the consumer price ranged from $71.3 \%$ to $85.1 \%$, while the wholesaler's share was $2.8 \%$ to $3.4 \%$, and the retailers share was $10.6 \%$ to $25.9 \%$. In other work, Hebicha (2009) found that an increase in the price of imported fish of US\$ $0.18 / \mathrm{kg}$ would increase per capita annual demand for local fresh fish by $0.26 \mathrm{Kg}$. The current study did not address the effect of consumer demand on fish price but this could be a topic for future research. There is seasonal demand for American catfish in US market with demand peaks occurring during Lent and late summer or early fall (Kinnucan and Miao, 1999)

Egyptian fish farmers are producing around three times as much farmed fish as they were ten years ago, so it is not sensible to depend on the same market supply 
chain they have always used, and one where they are completely dependent on wholesalers. As annual production by Egypt's fish farmers continues to grow there is likely to be continued downward pressure on selling prices. On the market side existing distribution channels are short with limited geographical reach (El-Gayar, 2003) and there is little processing or value addition to diversify product outlets (Macfadyen et al., 2012a). To maintain profitability and avoid a market crash, fish farmers are trying to become more efficient. Also fish farmers have to improve postharvest handling standard to increase the shelf-life of fresh fish in the market (ElGayar, 2003; Fiedi, 2004; Macfadyen, et al., 2012a).

\section{Acknowledgements}

This study was carried out as part of the IEIDEAS project implemented by WorldFish and funded by the Swiss Agency for Development and Cooperation (SDC). The project falls within the Livestock and Fish Research Program of the CGIAR. The authors are grateful for Dr. Malcolm Dickson for his encourage and support during editing of this paper.

\section{Abstract}

The current study investigates the relation between farmed fresh fish supply and sales prices in El-Obour wholesale market. The study also examines the market integration of farmed fish (tilapia, African catfish and mullet) together in the same market. Finally this article study the cointegration of farmed fish and frozen wild fish (wild tilapia, mackerel, Mediterranean horse mackerel, sardine and lizardfish) within the same market. Daily market data of fish sales volumes and selling prices through the calendar year of 2012 obtained from El-Obour wholesale market used in the analysis.

The results indicate that there is a negative relationship between the quantity of farmed tilapia supplied to El-Obour market and prices. The analysis shows that tilapia grade 1 and tilapia grade 2 are in the same market while farmed tilapia does not compete with other farmed fish (catfish and mullet). Tilapia size grades 1 and 2 compete in the market with frozen lizardfish and sardines while tilapia grade 3 competes with lizardfish and Mediterranean horse mackerel. The analysis does not indicate that there is market competition between catfish and frozen wild fish.

The implications are important as they show competition between farmed fish and popular imported frozen fish so increased importation of wild frozen fish could reduce the selling price of farmed tilapia impacting investment in fish farming businesses.

Keywords: Market integration, competition, farmed fish, tilapia, wild fish, Egypt.

\section{References}

1. Asche, F., T. Bjørndal, \& J.A. Young (2001) Market interactions for aquaculture products. Working paper No. 10/01. SNF-project No 5400. Foundation for Research in Economics and Business Administration. Bergen.

2. Asche, F., D.V. Gordon, \& R. Hannesson. 2004. Test for Market Integration and the Law of One Price: The Market for Whitefish in France. Marine Resource Economics, (19), 195-210. 
3. Asche, F. \& F. Steen (1998) The EU one or several fish markets: An aggregated market delineation study of the EU fish market. SNF report 61/98, FAIR project CT96-1814 DEMINT.

4. Béné, C., B. Bandi, \& F. Durville (2008) Liberalization reform, 'neo-centralism' and black market: The political diseconomy of Lake Nasser fishery development. Water Alternatives 1(2), 219-235.

5. CAPMAS (The Central Agency for Public Mobilization and Statistic) (2103) Bulletin of Labour Force (Apr. - June) 2013. CAPMAS, Cairo, Egypt.

6. Dickey, D.A. \& W.A. Fuller. (1979) Distribution of the Estimators for Autoregressive Time Series with a Unit Root. Journal of the American Statistical Association, 74, 427-31.

7. El-Gayar, O. (2003) Aquaculture in Egypt and Issues for Sustainable Development.

Aquaculture Economics \& Management. 7(12), 137-154.

8. El-Obour Wholesale Market. http://www.oboormarket.org.eg/Default.aspx.

9. El-Sayed, A-F.M. (2007) Analysis of feeds and fertilizers for sustainable aquaculture development in Egypt. In M.R. Hasan, T. Hecht, S.S. De Silva and A.G.J. Tacon (eds).

Study and analysis of feeds and fertilizers for sustainable aquaculture development. FAO Fisheries Technical Paper. No. 497. Rome, FAO. pp. 401422.

10. Engle, R. F. and C. W. J. Granger. 1987. Cointegration and Error Correction: Representation, Estimation and Testing. Econometrica, 55, 251-276.

11. EViews (2004) EViews 5 for Window. Quantitative Micro Software LLC, USA.

12. FAO (2012) Global Aquaculture Production Query 1950-2011, Rome Italy. http://www.fao.org/fishery/statistics/global-aquaculture-production/query/en.

13. Feidi, I. H. (2004) The Market for Seafood in the Area of Greater Cairo (Egypt). Center for Marketing Information and Advisory Services for Fishery Products in the Arab Region (INFOSAMAK).

14. Field, A. (2009) Discovering Statistics using SPSS (and sex and drugs and rock' n' roll). ( $3^{\text {rd }}$ ed.). London: Sage.

15. Fitzsimmons, K. (2008) Tilapia product quality and new product forms for international markets. In: Elghobashy, H., Fitzsimmons, K., Diab, A.S. (eds.) Proceedings of the $8^{\text {th }}$ International Symposium on Tilapia in Aquaculture. "From the pharaohs to the future" Cairo, Egypt, 12-14 Oct 2008, V. 1. pp. 1-10.

16. GAFRD (General Authority for Fisheries Resources Management) (2012) Statistics of Fish Production. GAFRD, Ministry of Agriculture and Land Reclamation, Egypt.

17. Green, B.W., Z. El Nagdy, \& H. Hebicha, (2002) Evaluation of Nile tilapia pond management strategies in Egypt. Aquaculture Research, 33, 1037-1048.

18. Hebicha, H. (2008) Vertical price linkages in the Egyptian tilapia market. In: Elghobashy, H., Fitzsimmons, K., Diab, A.S. (eds.) Proceedings of the $8^{\text {th }}$ International Symposium on Tilapia in Aquaculture. "From the pharaohs to the future" Cairo, Egypt, 12-14 Oct 2008, V. 1. pp. 665-678. 
19. Hebicha, H. (2009) Demand for Imported Fish Products in Egypt: A Cointegration and Error Correction Analysis. Journal Agricultural Sciences Mansoura University, 34 (5): 4501 - 4511.

20. Hebicha, H., S. Mohamed, \& G. Azazy (2009) Demand Function for Fresh Local Fish in Egypt and Some of its Applications. Journal of Applied Sciences, 24 (6): $195-206$.

21. Hebicha, H. \& A. Salama (2008) Marketing margins and elasticities of price transmission for tilapia, catfish and mullet in the Egyptian market. Egyptian Journal of Agricultural Economics, 18 (4): 1414-1423.

22. Hong, T.T.K. \& N.M. Duc (2009) Competition between US catfish and imported fish - A demand system analysis. Journal of Agricultural Science and Technology, 4,111-118.

23. IBM SPSS (2010) IBM SPSS Statistics for Windows, Version 19.0. Armonk, NY: IBM Corp.

24. Johansen, S. (1988) Statistical Analysis of Cointegration Vectors. Journal of Economic Dynamics and Control, 12, 231-54.

25. Johansen, S. (1995) Likelihood-Based Inference in Cointegrated Vector Autoregressive Models (New York: Oxford University Press).

26. Kinnucan, H.W. \& Y. Miao (1999) Media-specific returns to generic advertising: The case of catfish. Agribusiness, 15 (1), 81-99.

27. Macfadyen, G., A.M. Nasr Allah, \& M. Dickson (2012a) The market for Egyptian farmed fish. Study Report. WorldFish Center, Egypt. pp 54.

28. Macfadyen, G., A.M. Nasr Allah, D.A.R. Kenawy, M.F.M. Ahmed, H. Hebicha, A. Diab, S.M. Hussein, R.M. Abouzied, \& G. El. Naggar (2012b) Value-Chain Analysis - an assessment methodology to estimate Egyptian aquaculture sector performance, and to identify critical issues and actions for improvements in sector performance. Aquaculture, 362-363 (2012)18-27.

29. Nasr-Alla, A., Macfadyen, G., Dickson, M., Al-Kenawy, D., Fathi, M., \& ElNaggar, G., (2012) Value chain analysis of the Egyptian aquaculture sector. Proceedings of IIFET Conference in Tanzania from 16 to 20 July 2012. Tanzania

30. Norman-López, A. (2006) Competition between Different Farmed and Wild Species: The US Tilapia Market. Marine Resource Economics, 24, 237:251.

31. Norman-López, A. \& Asche, F. (2008) Competition between imported tilapia and US catfish in the US market. Marine Resource Economics, 23 (2), 199:214.

32. Norman-López, A. \& Bjørndal, T. (2009) Is tilapia the same product worldwide or are markets segmented? Aquaculture Economics \& Management 13 (2), 138154.

33. Radwan, I. (2008) Tilapia aquaculture in the Nile Delta 1990-2008. In: Elghobashy, H.,

Fitzsimmons, K., Diab, A.S. (eds.), Proceedings of the $8^{\text {th }}$ International Symposium on

Tilapia in Aquaculture. "From the pharaohs to the future" Cairo, Egypt, 12-14 Oct 2008, V. 1. pp. 605-611. 
تحديد أسعار اسماك مزارع المياه العذبة وتنافسها مع أسعار اسماك المصايد فى سوق الجملة

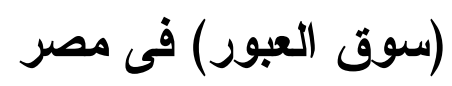

أحمد محمد نصر الله

الملخص

تبحث الدراسة الحالية العلاقة بين عرض اسماك مزارع المياه العذبة وسعر البيع فى سوق الجملـــة

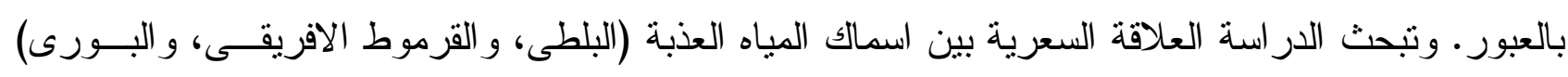

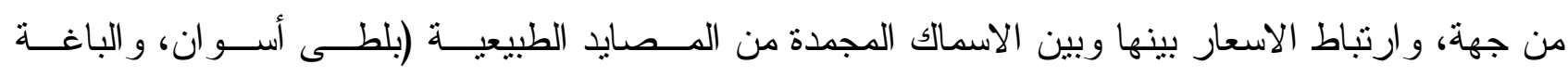

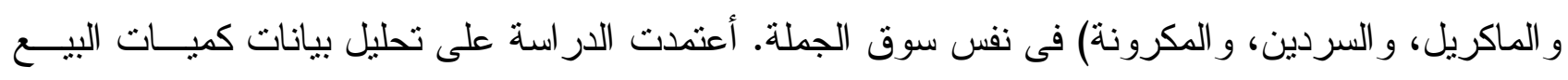

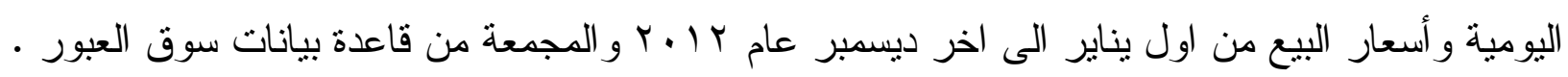

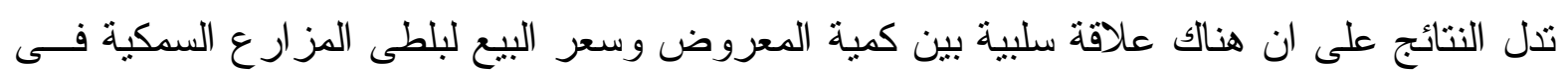

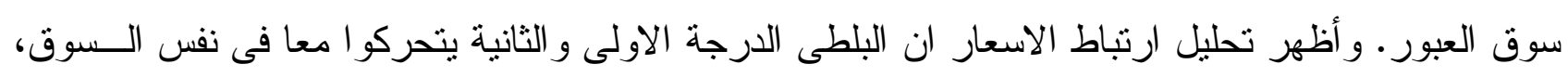

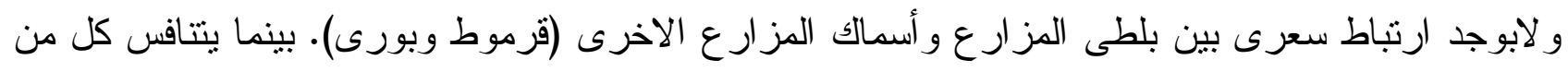

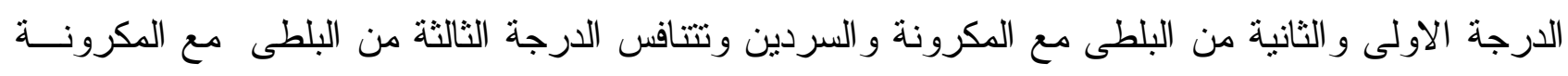

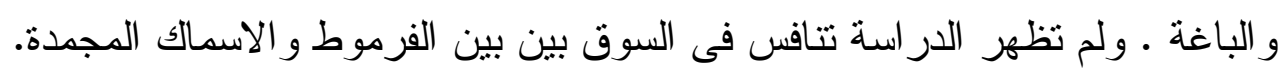

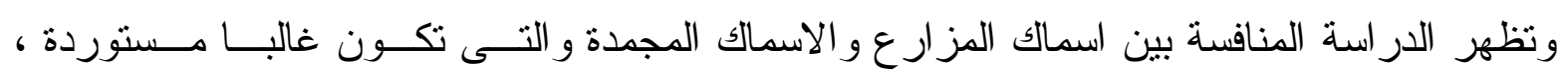
وبالتالى زيادة استير اد الاسماك المجمدة يقلل سعر البيع لبلطى المزارع مما يؤثز سلبا على الاستثمار ات فـى لإنى المز ارع السمكية. 